\title{
A Study of Vertical Circulation System in General Hospitals by Using Space Syntax
}

\author{
공간구문론을 이용한 종합병원 수직동선체계 연구
}

Lee, Hyunjin* 이현진 | Park, Jaeseung** 박재승

\begin{abstract}
Purpose: This study examines construction core plans for the users of vertical-typed general hospitals to effectively use the flow line. Methods: The study sampled representative 9 hospitals, calculated the depth value through Convex Map of Space Syntax and Justified Graph according to the determination of form of construction core, and analyzed its functional connectivity. Results: The analysis of the connectivity between operation core part and emergency part of core space with high importance in the hospitals showed that the types of $<$ Sev $>$ hospital and <Ajoumc $>$ hospital have the lowest depth value in the spatial phase diagram, where central treatment part and outpatient part are arranged well vertically. Elevators for patients at these hospitals are close to operation and emergency parts actually separated from the elevators for passengers. For shortening of flow line of patients and private movement environment, however, it is desirable to arrange the elevators for patients to be adjacent to the operation parts and to arrange the emergent patient entrances more effectivly to separate them from the flow line of visitors and guardians. Implications: Consideration should be taken into account for the effective flow line design. This study hopefully may serve as a stepping stone for the standard design of horizontal/vertical flow line
\end{abstract}

Keywords Vertical Circulation System, General Hospital, Space Syntax

주 제 어 수직동선체계, 종합병원, 공간구문론

\section{Introduction}

\subsection{Background and Objective}

우리나라 보건의료기관의 $93 \%$ 이상이 민간시설인데, 그 대 부분이 중.대도시에 위치하고 있다. 그리고 급격한 사회경제 의 발전은 대형종합병원의 신설이나 기존병원시설의 확충을 낳고 있다. 더구나 의료전달체계의 미정착과 치료중심의 수 가제도는 3 차 의료기관인 이런 대형종합병원에 쏠림현상을 보이고 있다.

뿐만 아니라 21세기에 들어와서 치료와 예방의학의 발전 으로 병원을 찾는 인구가 급격히 늘어나고 있고, 특히 의학 의 전문화와 세분화가 확대되면서, 이를 수용해야만 하는 병 원들이 고층화되고 있다. 국내외의 많은 연구가 수평형 병원

* Member, PhD., Department of Architecture, Graduate School of Hanyang University (Primary author: hjlee0323@hotmail.com)

** President, Professor, PhD., Department of Architecture Hanyang University (jaespark@hanyang.ac.kr)
설계의 중요성을 언급하고 있지만 도심형 병원 유형인 수직 형 종합병원에 대해서는 연구가 상대적으로 부족한 실정이 다. 따라서 수직동선의 연결을 통한 효율성의 제고와 코어 계 획의 적정성에 관한 연구가 절실히 요구된다.

본 연구는 국내 종합병원의 고층화, 대형화에 따른 필연적 인 수직유형의 종합병원의 이용자와 사용자가 수직이동 동 선을 원활하고 효과적으로 사용할 수 있도록 Space Syntax 의 Convex map과 Justified Graph를 통해 depth값을 산정하 여 코어의 기능 연계성 분석을 통해 수직동선체계를 분석한 다.

\subsection{Research Methods}

우리나라 병원의 발전사를 살펴보면 1964년 연세대학교 병원, 1974년 여의도 성모병원, 1967 년 한양대학병원 등 대 규모 종합병원이 설립되었지만, 1978년 서울대학병원 개축 으로 수직적 형태의 동선체계를 갖춘 최초의 종합병원이 도 입되었다. 1970년도부터 고도의 경제성장시대를 맞이하면서 
의료수요가 증가되고 의료시설이 양적으로 증대되었다. 1 인 당 $\mathrm{GNI}($ 국민총소득)의 급속한 성장을 보이면서 기업형 병원 이 출현하였다. 본 연구는 1990 년 이후의 설립된 병원을 선 정하였다.

규모에 있어서는 500 병상 이상의 중. 대형 9 개 병원을 선 정하였는데 1000 병상이 넘는 대형병원이 3 곳 이다. 본 연구 는 종합병원시설을 대상으로 하였으며 병원운영을 대상으로 살펴보면 기업형 사립병원, 공공병원, 대학부속병원, 선교사 립병원 등 최상의 진료를 내세우는 대표병원으로 선정하였 다.

선행연구 ${ }^{1)}$ 되어진 병원 부문별 공간구성에 대한 자료와 부 문별 상관관계도에 대한 연구를 바탕으로 상관관계의 중요 도를 도출하였으며 이중 중요도가 높으며 수직으로 연계되 어 있는 수술부와 응급부, 급식부와 병동부의 기능연계성을 중점으로 연구하였다.

공간구문론은 사례병원의 공간적 구성 특성을 파악하고 공 간의 연결 관계를 분석하기 위해 객관화 또는 계량화 할 수 있는 수학적 모델이다. 이에 따라 공간구성의 특성을 객관적 으로 분석하여 사례병원의 수직적 기능공간의 연계성이 어 떻게 이루어졌는지를 파악하고, 이를 통해 코어의 기능과 역 할에 대한 자료를 확보한다.

\section{Theoretical Consideration}

\subsection{Consideration of Vertical Circulation Sys- tem}

다른 층간의 수직이동은 대상에 따라 계단 또는 승강기, 에 스컬레이터, 덤웨이터, 기송관, 물류이동시스템에 의해 가능 하다. 이런 일련의 수직으로 이동되는 이용자 또는 사용자와 물류의 체계를 수직동선시스템이라 정의 한다.

코어(core)의 사전적 의미는 과일의 속 같은 사물의 중심 부, 또는 핵심을 뜻한다. 기능의 중심이 되는 시설 또는 시설 군이라는 건축적 개념으로서의 코어는 건물의 공통시설(계 단, 승강기, 화장실, 설비공간 등)이 집중해 있는 중심 부분으 로 건축물의 상하를 기능적으로 연결시키는 핵심공간을 일 컫는다.

일반 건축물에서 코어의 도입은 구조와 설비의 집중화를 통해 효율적인 운영을 위한 이유에서이지만, 병원처럼 공간 구조의 연계성이 중요시되고, 다양한 이용자와 물품의 이동 이 많은 시설에 있어서는 적절한 코어의 배치와 규모의 계획 은 원활하고 신속한 병원동선의 흐름 뿐만 아니라 성장, 변화 하는 병원건축계획에 있어서는 더욱 중요한 계획요인이 된

1) 이현진, 박재승, 환자중심의 수직코어 계획을 위한 종합병원 부 문간 상관배치에 관한 연구, 한국의료복지시설학회, 19권2호, 2013, pp31-40
다. 코어계획은 거실공간과는 달리 생산성이나 수익성이 낮 기 때문에 최소한으로 계획하는 경우가 많다. 하지만 수직병 원의 상하를 연결하는 중추적 역할을 하는 코어는 콤팩트한 계획에서 벗어나 수직적 공간연결의 적절하고 효율적인 계 획이 필요하겠다.

수직형 종합병원에서 코어는 환자, 보호자, 방문자, 의료진, 간호사 사체, 소독물, 오염물, 약품, 린넨, 혈액, 급식 등 다양 한 인적 물적 대상이 원활하게 이동할 수 있어야 하며, 또 그 러한 공간유형에서 건축코어인 계단과 승강기는 수직교통을 원활히 하게하는데 필수적인 요소로서 병동부와 외래진료부, 중앙진료부, 공급부, 서비스부의 주요 기능 실을 긴밀히 연결 시켜주는 중요한 역할을 한다.

\subsection{Consideration of Space Syntax}

공간구문론(Space Syntax)은 Hillier \& Hanson ${ }^{2}$ 에 의해 개 발한 공간구조분석 이론이다. 공간구문론은 건축평면상에 나 타난 공간 하나하나를 독립된 단위요소로 보고, 각 공간간의 연결 관계를 객관적인 수치나 그래프로 나타낼 수 있다. 공간 구문론에서 공간의 구조특징을 표현하는 기본 개념은 "깊이" (depth)이다. '깊이'는 상하 공간 사이의 거리를 나타내는 것 으로 한 공간에서 다른 공간으로의 거리를 1 로 정하고, '깊 이'가 높으면 높을수록 거쳐야 하는 공간 수가 많아진다. 그 러므로 접근성이 떨어진다고 할 수 있다. 이러한 방법으로 '깊이'를 산정되기 때문에 공간 배치구조에 따라 값이 결정된 다. ${ }^{3)}$

특정 공간의 이용패턴과 움직임을 파악하여 공간 배치에 대한 검토를 하는 것이 건축설계의 중요한 요소가 되고 있다.

Hillier는 건물과 도시의 공간적 관계를 객관적으로 표현하 는 2가지 방법을 연구하였는데, 하나는 볼록 공간도(Convex map)이고 다른 하나는 시각축도(Axial Map)이다. ${ }^{4)}$

1) Evaluation of Depth in Core

(1) Convex map

어떤 지점에서도 다른 모든 지점으로 직접 이동할 수 있고 동시에 주위를 볼 수 있는 2차원의 공간이다. 다시 말하면, 전체 공간 구성 내에서 우리가 어디에 있는가를 설명해 주는 지역적 특성을 갖고 있다.

(2) Justified Map and Depth

특정 공간조직을 단위공간으로 분해한 다음, 이들 간의 상 호관계를 가시적으로 표현하기 위해 이용하는 도해방식의

2) Bill Hillier \& Julienne Hanson, The Social Logic of space, Cambridge University Press, 1984, PP90-92

3) 조영행, 공간구문론을 이용한 치매전문요양소의 공간구성 특성, 대한건축학회논문집, 26권 7호, 2010.7, pp28

4) 이수경, 공공도서관의 공간구성과 유형적 특성에 관한 연구-공간 구문론의 깊이와 회로경험의 관점에서, 한양대학교 박사학위논 문, 2009, pp81 
하나가 공간위상도이다. 단위공간을 고리(connection)로 연 결하여 외부에서부터 각 공간들이 어떻게 연결되어 있는지 한눈에 파악할 수 있도록 특정지점으로부터 각 단위공간의 관계를 위상학적으로 표현한 것이다. 이를 통해 연결과 깊이 의 문제가 드러날 수 있기를 기대한다.

공간위상도에서는 폐곡선으로 이루어진 링(ring)이 존재하 는데, 이는 이 링으로 연결된 각 공간에서 다른 공간으로 이 동할 때, 한 루트(route)만이 아닌 여러 가지 루트를 선택하여 이동할 수 있다는 것을 나타낸다. 어떤 공간으로 이동 할 때 반드시 하나의 공간만을 거치는 것이 아니라 여러 가지 선택 을 함으로써 좀 더 다양한 공간 경험을 할 수 있다는 장점을 갖고 있다.

\section{Investigation of Sample Hospitals}

\subsection{General Summary of Samples}

1990년 전후 한국 종합병원의 발전은 의료수요의 증가만 큼 양적성장을 시작하였다. 1,000 병상이 넘는 종합병원이 여 럿 생겨났다. 과거 병원이 환자치료 중심의 기능주의 병원이 었다면 21세기 이후부터는 의료기술의 발전과 유니버설 디 자인이 반영된 상업중심의 디자인으로 환자중심병원이 강조 되기 시작한 것이다. 크고 화려한 로비, 아트리움, 호스피탈 스트리트가 만들어지고 진료의 전문화, 노후시설의 리모델 링, 디지털시대에 변화에 대응한 병원건축, 친환경과 지속가 능한 병원설계 등의 이슈들이 계속적인 발전을 거듭하고 있 다. 이러한 병원건축 변화의 흐름 속에서 한국 종합병원의 변화를 담고 있는 대표적인 병원 9곳을 사례병원으로 선정하 였다.

[Table 1] Summary of Samples

\begin{tabular}{c|c|c|c|c|c|c}
\hline 병원명 & 개원 & 병상수 & 건축면적 $\left(\mathrm{m}^{2}\right)$ & 연면적 $\left(\mathrm{m}^{2}\right)$ & 규모 & 소재지 \\
\hline Ajoumc & 1994 & 886 & $11,675.00$ & $100,260.00$ & $\mathrm{~B} 2 ~ 14$ & 수원 \\
\hline Smc & 1994 & 1250 & $19,261.64$ & $212,913.98$ & $\mathrm{~B} 5 \sim 20$ & 서울 \\
\hline Nhimc & 2000 & 744 & $8,355.00$ & 104.392 .00 & $\mathrm{~B} 5 \sim 13$ & 일산 \\
\hline Snubh & 2003 & 835 & $16,616.95$ & $135,909.36$ & $\mathrm{~B} 3 \sim 15$ & 분당 \\
\hline Kuh & 2005 & 819 & $7,365.28$ & $86,776.29$ & $\mathrm{~B} 4 \sim 13$ & 서울 \\
\hline Sev & 2005 & 1004 & $14,318.41$ & $171,290.00$ & $\mathrm{~B} 3 \sim 21$ & 서울 \\
\hline Bsm & 2006 & 573 & $5,512.81$ & $60,076.00$ & $\mathrm{~B} 3 \sim 11$ & 부산 \\
\hline Pnuyh & 2008 & 778 & $18,505.02$ & $125,374.54$ & $\mathrm{~B} 2 \sim 12$ & 부산 \\
\hline Cmc-s & 2009 & 1085 & $36,544.86$ & $320,428.49$ & $\mathrm{~B} 6 \sim 20$ & 서울 \\
\hline
\end{tabular}

\section{Depth through Using Space Syntax}

본 연구에서는 중요도 3 에서 수직 연결되어 있는 수술부와 응급부의 연결현황을 볼록공간도와 공간위상도를 통해 분석
하여 부문 간 연계 깊이를 파악하고, 또 수직적으로 두 기능 공간을 연결하는 코어의 배치현황을 평가하려한다. 또한 급 식부에서 병동부에로의 동선에 관한 공간구성 현황을 분석 하여 승강기의 배치와 병동형태와의 연계성을 조사한다. 이 는 기단부의 수직이동뿐만 아니라 병동부 기준층의 수직이 동 현황을 파악하여 메인코어와의 기능연계성을 조사하려는 시도이다.

어떤 평면공간에서의 연결은 개구부가 있으면 연결하고 개 구부가 없으면 연결하지 않으면 되기 때문에 큰 문제가 없으 나, 평면과 평면 사이를 연결하는 단위공간의 경우에는 아직 까지 명확하게 정리된 연구가 없다. 따라서 승강기의 경우 승 강기 전체를 하나의 단위공간으로 통합하여 연결하는 것으 로 좁혀 처리하고, 계단의 경우에는 각 층을 하나의 단위공간 으로 하는 방법을 선택하였다.

\subsection{Depth of Operation Part - Emergency Part}

수술부 환자와 의사 그리고 간호사의 이동 동선은 다르다. 따라서 수술실로의 이동진입 과정은 서로 분리된다.

[Table 2] Relations in the Movements between Operation part-Emergency part ${ }^{5)}$

\begin{tabular}{|c|c|c|c|c|c|c|c|c|c|c|}
\hline $\begin{array}{l}\text { 배 } \\
\text { 점 }\end{array}$ & $\begin{array}{l}\text { 수술부- } \\
\text { 응급부 }\end{array}$ & 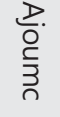 & $\aleph_{ૂ}$ & 孞. & $\begin{array}{l}\cong \\
\frac{n}{\frac{\sigma}{0}} \\
\frac{0}{J}\end{array}$ & $\begin{array}{l}\frac{\pi}{5} \\
\text { J }\end{array}$ & 莡 & $\begin{array}{l}\text { W } \\
3\end{array}$ & 冚 & $\begin{array}{l}\hat{3} \\
\hat{i}\end{array}$ \\
\hline \multirow{3}{*}{3} & & V & C & V & V & V & V & C & C & V \\
\hline & $\begin{array}{c}\text { 수술부 } \\
\text { 층수 }\end{array}$ & $\begin{array}{c}\text { 지상 } \\
3\end{array}$ & $\begin{array}{c}\text { 지상 } \\
3\end{array}$ & $\begin{array}{c}\text { 지상 } \\
3\end{array}$ & $\begin{array}{c}\text { 지상 } \\
3\end{array}$ & $\begin{array}{c}\text { 지상 } \\
3\end{array}$ & $\begin{array}{c}\text { 지상 } \\
5\end{array}$ & $\begin{array}{c}\text { 지상 } \\
3\end{array}$ & $\begin{array}{c}\text { 지상 } \\
2\end{array}$ & $\begin{array}{c}\text { 지상 } \\
5\end{array}$ \\
\hline & $\begin{array}{c}\text { 응급부 } \\
\text { 층수 }\end{array}$ & $\begin{array}{c}\text { 지상 } \\
1\end{array}$ & $\begin{array}{c}\text { 지상 } \\
1\end{array}$ & $\begin{array}{c}\text { 지상 } \\
1\end{array}$ & $\begin{array}{c}\text { 지상 } \\
1\end{array}$ & $\begin{array}{c}\text { 지상 } \\
1\end{array}$ & $\begin{array}{c}\text { 지상 } \\
1\end{array}$ & $\begin{array}{c}\text { 지상 } \\
1\end{array}$ & $\begin{array}{c}\text { 지하 } \\
1\end{array}$ & $\begin{array}{c}\text { 지상 } \\
1\end{array}$ \\
\hline
\end{tabular}

\section{1) Depth of <Ajoumc > Hospital}

병원의 평면을 살펴보면 수술부는 지상3층, 응급부는 지상 1 층에 위치한다. 환자용 승강기 홀은 승객용 승강기 홀과 분 리되어 계획되어 있다. 승객용 승강기는 호스피탈스트리트에 면해 배치되어 있으며, 환자용 승강기는 지상1층에 서브복도 (CO5)에 면해 있으며 환자용 승강기홀에서 수술부 출입구가 면해 있어 신속한 환자진입이 가능하며, 응급부는 서브복도 (CO5)를 통과하면 응급실 출입구가 바로 인접해 있다.

승강기 $\mathrm{E} 13$ 은 응급실에서 3층 응급집중치료실로의 별도의 승강기가 계획되어 있으며 이는 수술부층과 복도로 연결되 어 있다.

5) 이현진, 박재승, 환자중심의 수직코어 계획을 위한 종합병원 부 문간 상관배치에 관한 연구, 한국의료복지시설학회, 19권2호, 2013, pp37 


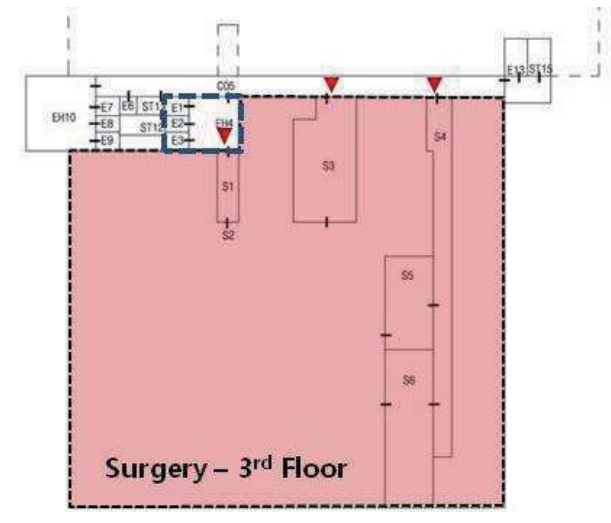

[Figure 1] Convex map of <Ajoumc $>$ Hospital (Surgery)

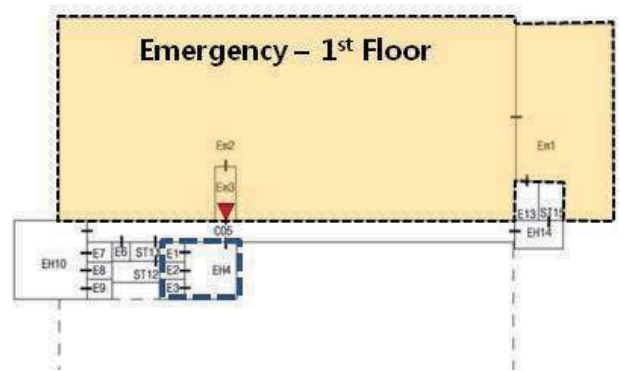

[Figure 2] Convex map of <Ajoumc > Hospital (Emergency)

공간위상도를 통해 공간구조를 분석한 결과, 응급실에서 환자용승강기까지의 깊이는 4단계이며, 환자용승강기에서 수술부까지의 공간깊이는 3단계로 응급실에서 수술부까지 는 총7단계의 공간깊이를 나타낸다. $\mathrm{EH} 14$ 의 승강기홀은 한 방향의 복도에만 면해 있어 응급부에서 수술부까지의 공간 의 이동경로는 하나의 경로로 집중되는 양상을 보인다. 연결 도가 높은 $1 \mathrm{CO} 5$ 와 $3 \mathrm{CO}$ 는 공간들이 집중되는 복도공간으로 다중심적 공간임을 알 수 있다.

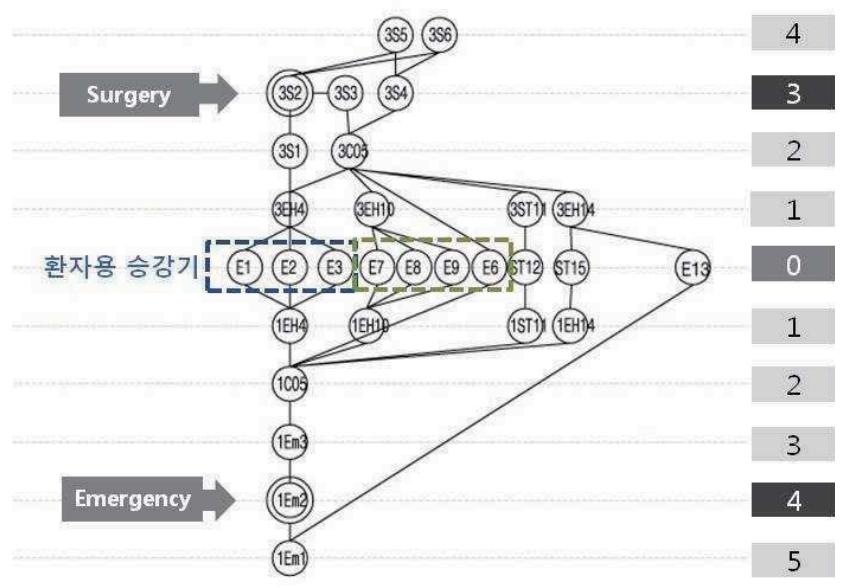

[Figure 3] Justified graph of <Ajoumc > Hospital (Surgery Emergency)
3층 승강기홀(3EH4)에서 바로 수술부로 수술환자는 진입 하지만 통원수술실로의 접근은 $3 \mathrm{CO} 5$ 의 복도에서 별도로 진 입하도록 되며, 수술 후 회복된 환자는 3CO5로 출구가 계획 되어 있으며, 간호사, 의사, 직원 동선은 3CO5에서 3S4-3S6 의 별도의 동선이 계획되어 우회하여 진입하도록 되어 있으 며, 환자진입에 우선하여 환자용승강기를 배치된 것이 특징 이다.

2) Depth of <Smc> Hospital

$<\mathrm{Smc}>$ 병원은 지상1층 응급부에서 환자용승강기(E1, $\mathrm{E} 2, \mathrm{E} 3, \mathrm{E} 4)$ 로 지상3층의 수술부로 이동하려면 연결브리지 (3CO28, 3CO29)를 지나야 수술실(3S10)의 준청결복도로 접 근이 가능하다. 호스피탈 스트리트를 지나 다른 블록에 위치 한 수술실까지의 공간깊이는 총12단계로 응급부 처치실에서 환자용승강기까지는 5 단계의 깊이를 환자용승강기에서 지 상3층 수술부의 준청결복도까지의 깊이는 7단계로 사례병원 중 가장 깊은 것으로 나타났다. 환자승강기홀 $(3 \mathrm{EH})$ 는 양측 에 복도(3CO23, 3CO24)가 면해 2방향으로 나뉘어 동선이 분 산됨을 보여준다.

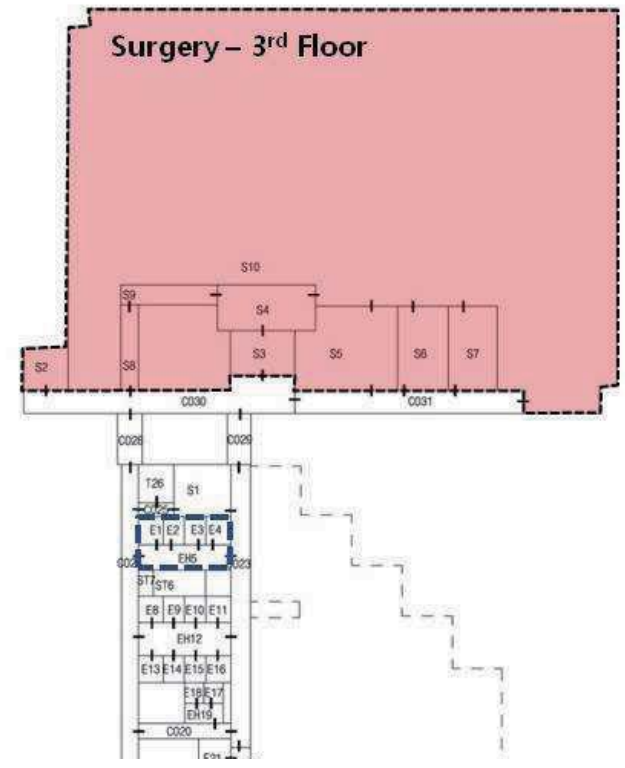

[Figure 4] Convex map of $<$ Smc $>$ Hospital (Surgery)

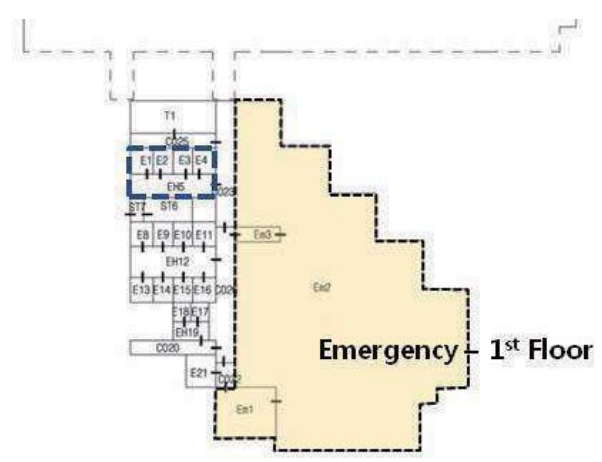

[Figure 5] Convex map of $<$ Smc $>$ Hospital (Emergency) 


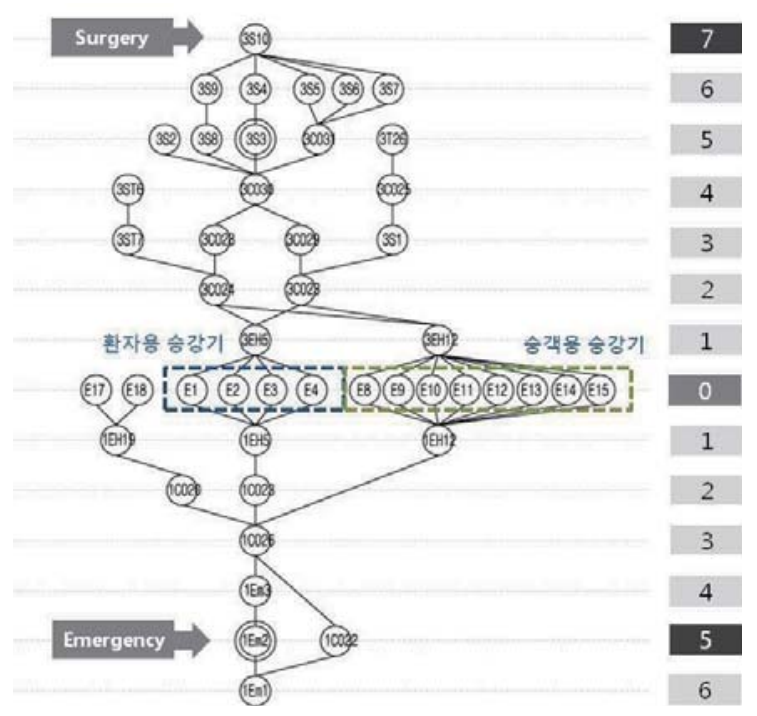

[Figure 6] Justified graph of $<$ Smc $>$ Hospital (Surgery Emergency)

\section{3) Depth of <Nhimc > Hospital}

<Nhimc> 병원의 공간깊이를 살펴보면 수술부는 지상3층 환자용 승강기 홀에서 공용의 복도(3CO10, 3CO11, 3CO12) 를 지나야 수술부로 진입이 가능하며, 이로 인해 환자용승강 기에서 수술부까지의 깊이가 7로 사례병원중 제일 깊은 값을 나타냈다. 지상 1 층의 메인코어는 호스피탈 스트리트에 면해 있어 응급환자는 공용의 공간을 거쳐 진입해야 한다.

공간위상도를 통해 공간구조를 분석한 결과 응급실에서 환 자용승강기까지의 깊이는 5 단계이며 환자용승강기에서 수술 부까지는 7단계로 총 12 단계의 공간깊이를 나타낸다.

환자용 승강기(E1, E2, E3, E4)와 승객용 승강기(E5, E6, E7, $\mathrm{E} 8)$ 가 하나의 홀(EH9) 공간에 있어 동선의 강한 집중의 형태 를 보이지만 홀 공간의 혼잡이 예상된다.

\section{Surgery $-3^{\text {rd }}$ Floor}

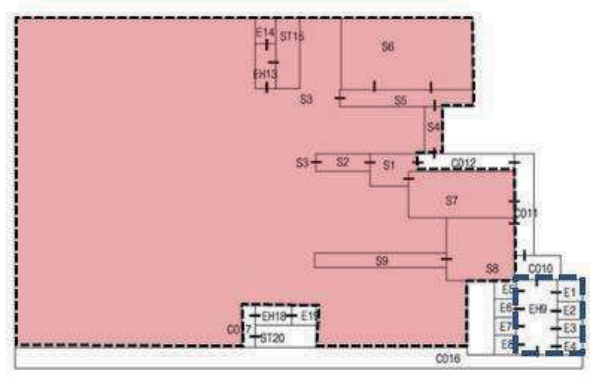

[Figure 7] Convex map of $<$ Nhimc $>$ Hospital (Surgery)

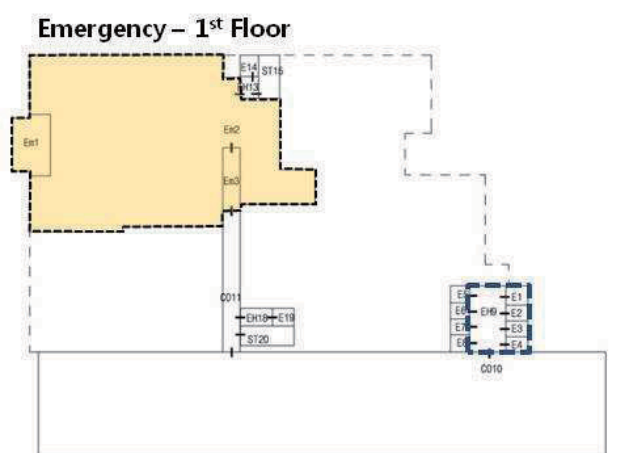

[Figure 8] Convex map of < Nhimc $>$ Hospital (Emergency)

E14는 응급부 내부에서 수술부 준청결복도까지 바로 연결 되는 비상용승강기가 있으며 E19는 지상1층 공용복도에서 지상3층 공용복도까지 연결하는 비상용승강기도 있다.

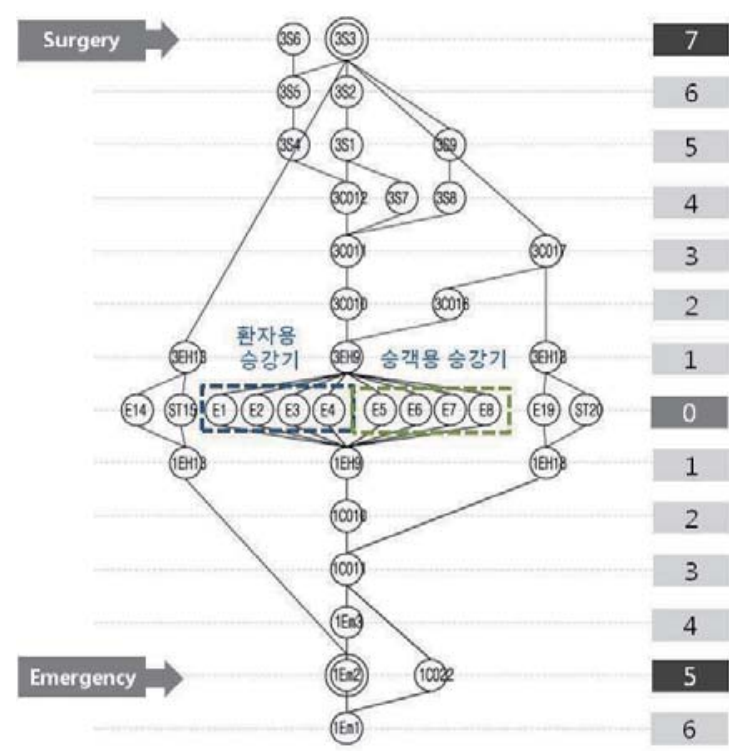

[Figure 9] Justified graph of <Nhimc $>$ Hospital (Surgery Emergency)

4) Depth of <Snubh $>$ Hospital

<Snubh>병원은 지상3층에 수술부, 지상1층에 응급부가 배치되어 있으며, 상하 같은 블록 안에 배치되어 있다. 메인 코어는 환자용승강기 4대 승객용승강기 5대가 인접 배치되 어 있으며 다른 승강기홀로 분리되어 있지만 1 면에만 복도 (CO12)가 면해 있어 모든 환자와 방문객, 직원의 동선이 한 곳으로 집중됨을 알 수 있다. 공간깊이를 분석한 결과, 응급 실에서 환자용승강기까지의 깊이 값은 5 이며 수술부에서 환 자용승강기까지의 공간깊이 값은 7 의 공간깊이를 나타낸다. 응급부에서 수술부까지의 공간의 이동경로는 대체적으로 분 산되지 않고 집중되는 것을 알 수 있었다.

메인코어에서는 환자용과 일반인용이 분리되어 있지만 $3 \mathrm{CO} 12$ 에서 다시 합류하는 동선으로 완전 분리되지는 못하 
였다. 수술부 내부 준청결공간까지의 깊이가 다른 사례의 병 원보다 깊어서 준청결공간인 3S5까지 가는데 S1-S2- S3-S4 를 거쳐야 하는 평면을 가져 상대적으로 높은 깊이 값을 나 타냈다. 이는 공용의 홀과 접하는 면이 좁아 회복 후 동선, 간 호사, 의사, 직원의 동선과 환자의 동선이 수술부 내부에서 분리되기 때문인 것으로 파악된다.

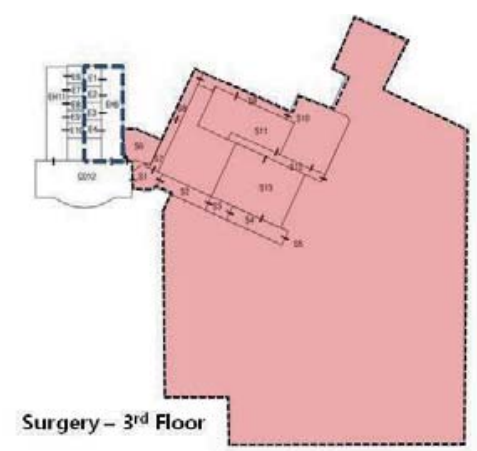

[Figure 10] Convex map of $<$ Snubh $>$ Hospital (Surgery)

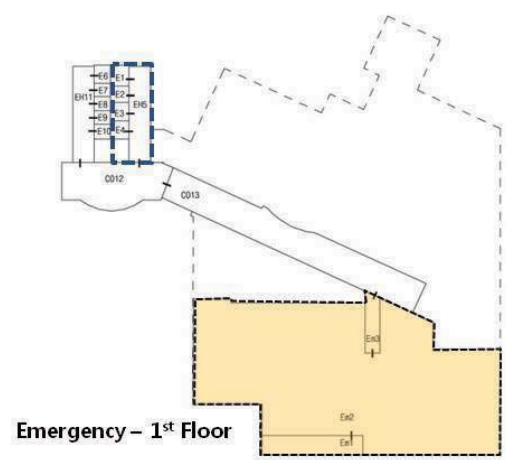

[Figure 11] Convex map of <Snubh $>$ Hospital (Emergency)

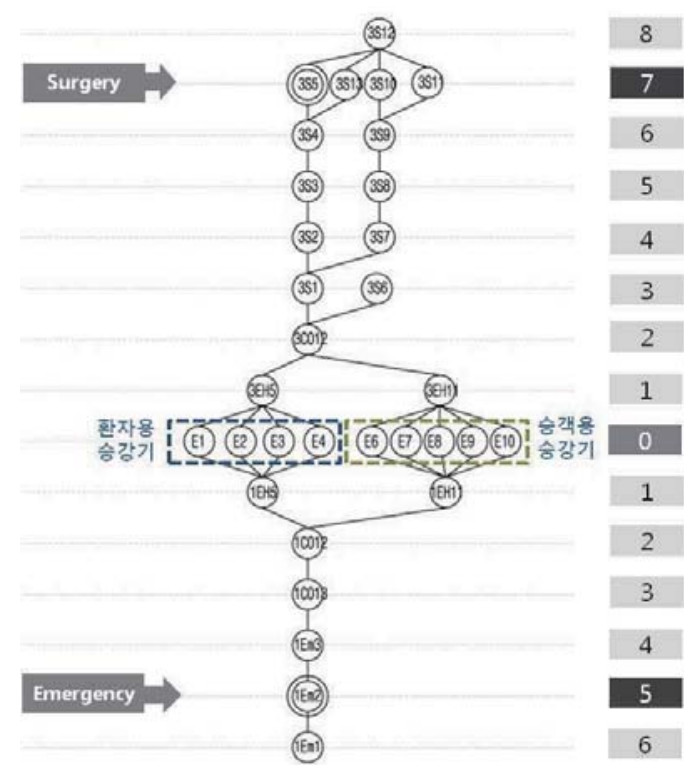

[Figure 12] Justified graph of $<$ Snubh $>$ Hospital (Surgery Emergency)

\section{5) Depth of <Kuh> Hospital}

<Kuh>병원의 공간위상도를 통해 공간깊이를 분석한 결과, 응급실에서 환자용승강기까지의 깊이 값은 4 이며 수술부에 서 환자용승강기까지의 공간깊이 값은 5 의 공간깊이를 나타 낸다. 응급부에서 수술부까지의 공간의 이동경로는 메인코어 를 통해 대체적으로 분산되지 않고 집중되지만, 비상용승강 기인 서브코어가 중앙에 밀집된 센터코어형의 유형을 나타 내므로 여러 방향으로의 루트가 나뉘는 것을 알 수 있다. 메 인 코어를 중심으로 이중복도를 형성한 유형의 코어는 환자 와 의사의 동선을 2 방향으로 분리하지만 하나의 승강기홀을 공유하고 있어 환자와 방문객, 의사, 간호사의 동선이 매우 혼잡함이 예상된다.

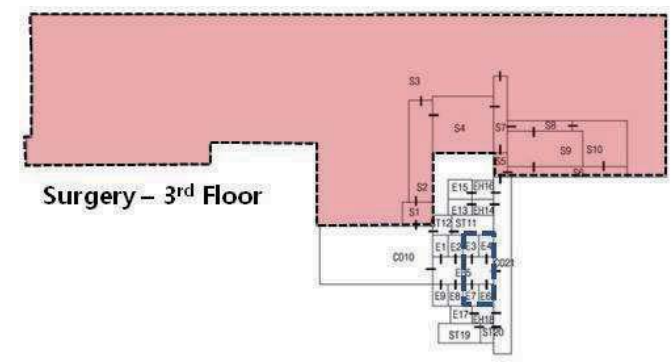

[Figure 13] Convex map of <Kuh $>$ Hospital (Surgery)

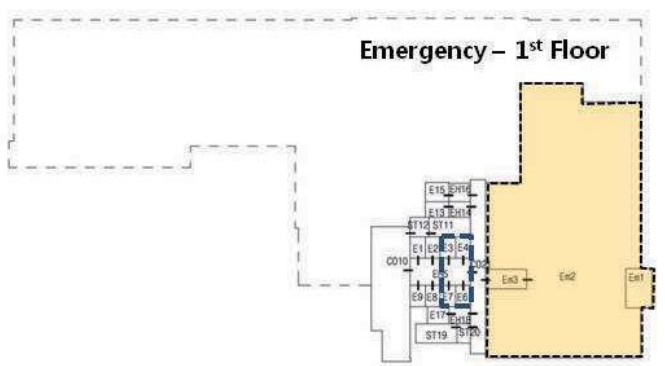

[Figure 14] Convex map of <Kuh $>$ Hospital (Emergency)

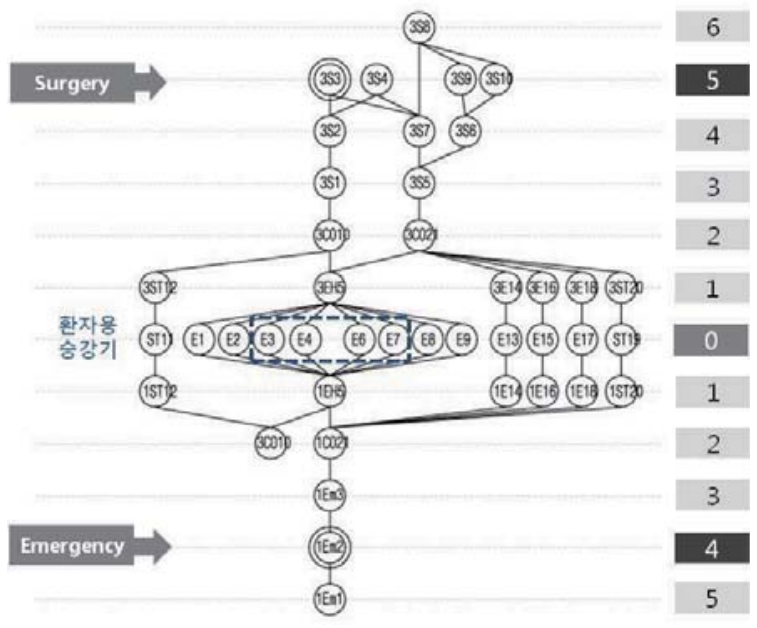

[Figure 15] Justified graph of <Kuh> Hospital (Surgery Emergency) 
6) Depth of <Sev> Hospital

<Sev>병원의 공간위상도를 통해 공간구조를 분석한 결 과, 응급실에서 환자용승강기까지의 깊이 값은 4 이며 수술 부에서 환자용승강기까지의 공간깊이 값은 4 로 사례병원 중에는 <Ajoumc>병원 다음으로 가장 낮은 깊이 값을 보인 다. <Sev>병원 수술부와 응급부, 코어배치의 특징을 살펴보 면, 환자용승강기와 승객용승강기는 서로 반대에 면하는 복 도 3CO17과 3CO19에 면해있어 환자와 방문객 또는 보호자 와의 동선은 완전 분리된다. 환자용승강기는 3CO17을 거쳐 바로 수술부로 진입할 수 있게 배치되어 있으며, 보호자는 승 객용승강기를 이용해 우회되는 동선으로 3CO19-3CO20-3$\mathrm{CO} 21$ 을 거쳐야 $3 \mathrm{CO} 17$ 의 복도와 만나도록 계획되어 있다.

응급부에서 수술부까지의 공간 이동경로는 메인코어를 통 해 대체적으로 분산되지 않고 집중되고, 환자 동선과 보호자 동선이 응급실 내부에부터 분리되므로 환자의 이동이 독립 적으로 이루어지며 프라이버시와 안전, 청결이 유지됨을 알 수 있다.

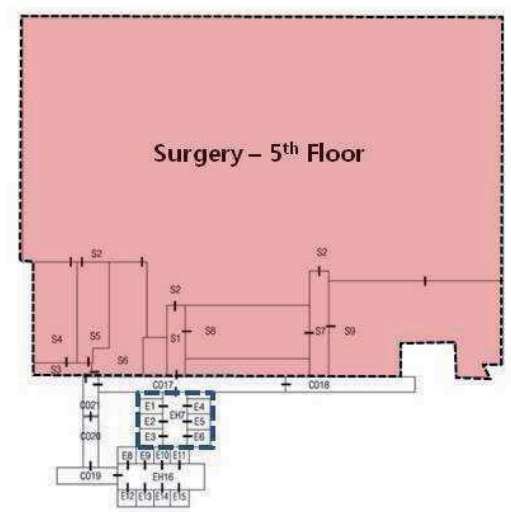

[Figure 16] Convex map of $<$ Sev $>$ Hospital (Surgery)

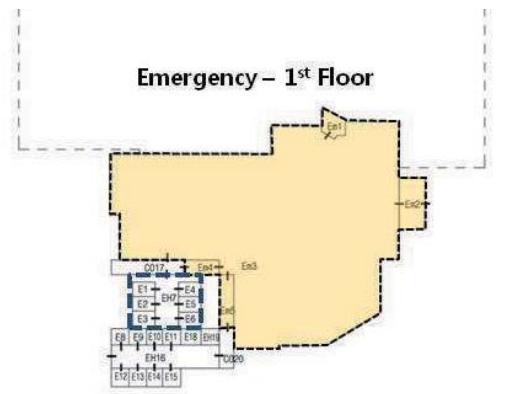

[Figure 17] Convex map of <Sev>Hospital (Emergency)

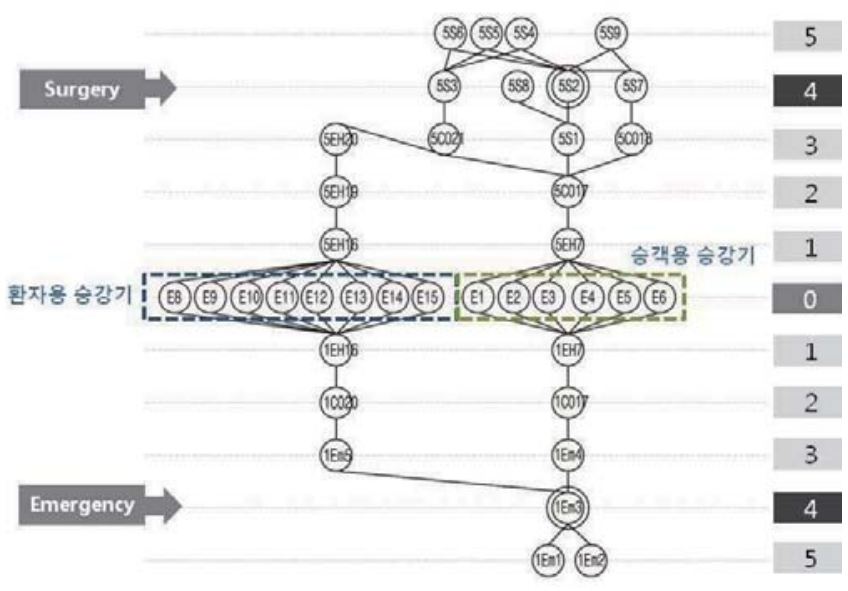

[Figure 18] Justified graph of <Sev> Hospital (Surgery Emergency)

\section{7) Depth of <Bsm> Hospital}

<Bsm>병원의 공간구성을 살펴보면 지상3층의 수술부, 지 상1층에 응급부가 배치되어 있다. 메인코어는 환자용승강기 와 승객용승강기가 EH7에 집중 배치되어 있으며 이는 $\mathrm{CO} 8$ 의 메인복도에 바로 면해 있어 인지성과 집중성이 뛰어 나지 만 환자 동선이 보호자 및 다른 동선과 분리되지 못하는 특 징을 가지고 있다. 이에 외래뿐만 아니라 수술부, 응급부등의 부서 진입은 각 층마다 $\mathrm{CO} 8$ 의 복도에서 진입되도록 되어 있 다.

공간위상도를 통해 공간깊이를 분석한 결과, 응급실에서 환자용승강기까지의 깊이 값은 5 이며 수술부에서 환자용 승강기까지의 공간 깊이 값은 4 로 나타났다. 연결도가 높은 $3 \mathrm{CO}$ 은 공간들이 집중되는 복도공간으로 다중심적 공간임 을 알 수 있다.

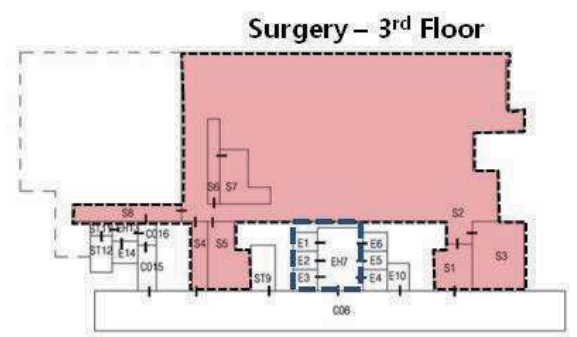

[Figure 19] Convex map of <Bsm $>$ Hospital (Surgery)

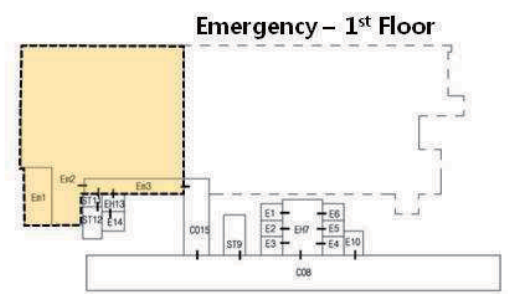

[Figure 20] Convex map of <Bsm > Hospital (Emergency) 


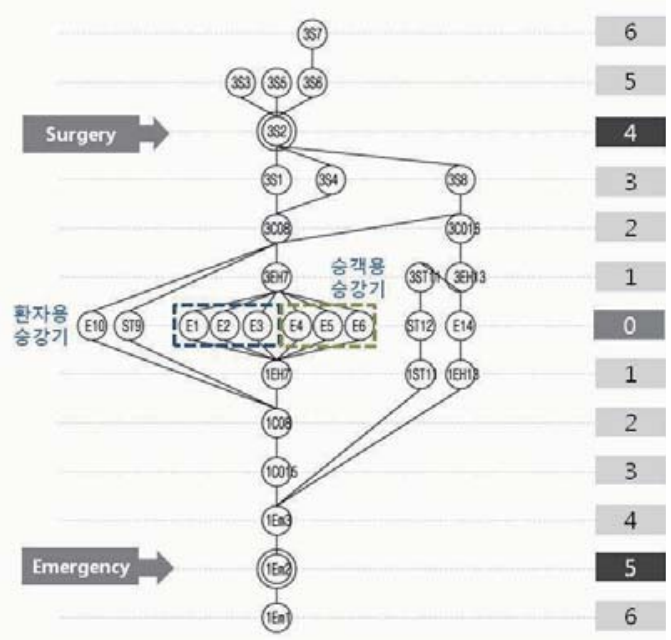

[Figure 21] Justified graph of $<$ Bsm $>$ Hospital (Surgery Emergency)

8) Depth of <Pnuyh > Hospital

<Pnuyh>병원의 공간위상도를 통해 공간구조를 분석한 결 과, 응급실에서 환자용 승강기(중앙 진료부에 면한 별도의 승 강기 $\mathrm{E} 1, \mathrm{E} 6$ )까지의 깊이는 5단계이며 수술부에서 환자용 승 강기까지의 공간깊이는 6 단계로 응급실에서 수술부까지는 11 단계의 공간깊이를 나타낸다.

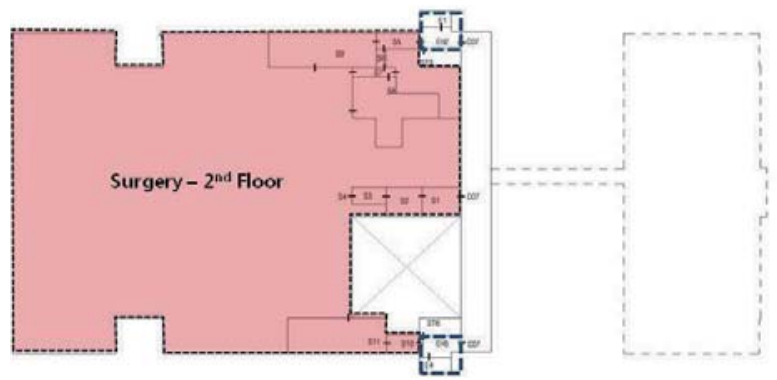

[Figure 22] Convex map of <Pnuyh > Hospital (Surgery)

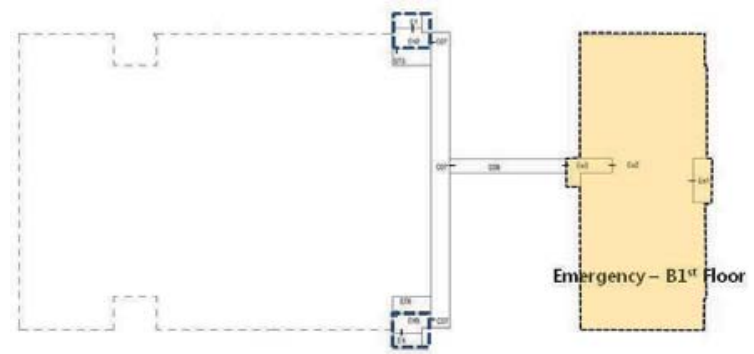

[Figure 23] Convex map of <Pnuyh > Hospital (Emergency)

<Pnuyh>병원은 병동부의 메인코어를 이용하지 않고 중앙 진료부에 있는 별도의 코어를 이용하는데, 중앙진료부의 코 어는 외주부에 배치되어 있어서 연결 루트가 단순하고 명확 함에도 불구하고 공간구성 깊이는 다른 수직형 병원의 사례 와 다르지 않음을 알 수 있다. 이는 응급부의 외부에서 진입
을 원활히 하고자 외주부에 면한 반면, 수술부는 가장 넓은 공간을 확보하기 위해 내주부에 배치되어 동선이 단순하지 만 복도로 인해 깊이가 깊어짐을 알 수 있다.

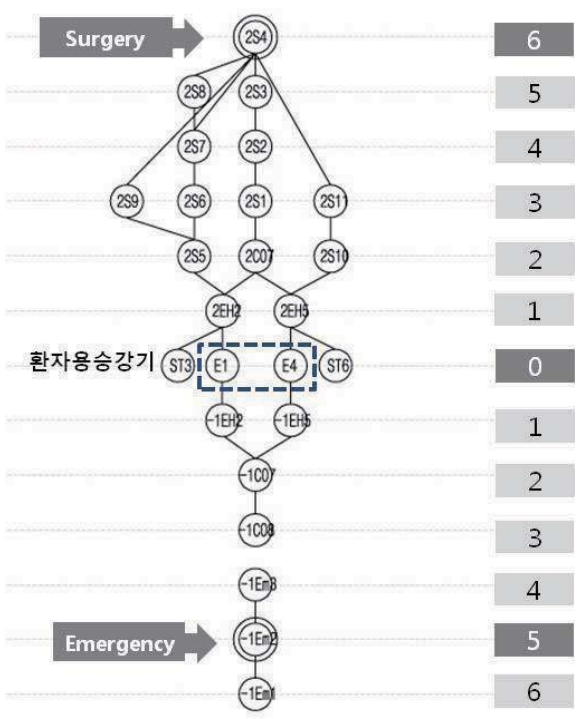

[Figure 24] Justified graph of < Pnuyh> Hospital (Surgery Emergency)

\section{9) Depth of $<$ Cmc-s $>$ Hospital}

<Cmc-s>병원은 지상5층에 수술부와 지상1층에 응급부가 위 치되어 있으며, 메인코어는 환자용승강기(E1 E6)와 승객용승강기 (E9 E16)는 3CO8복도를 사이에 두고 분리되어 있다. 승강기 홀은 수술부 준청결공간으로 진입되는 진입구가 계획되어 있지만, 주된 동선은 $3 \mathrm{CO}$ 에서 전처리실을 통해 진입되도록 계획되어 있다. 공간 위상도를 통해 공간깊이를 분석한 결과, 응급실에서 환자용승강기까 지의 깊이 값은 5 이며 수술부에서 환자용승강기까지의 공간깊이 값 은 6 로 나타났다.

응급실에서 메인코어로의 경로는 매우 명쾌하고 단순하며, 수술부층의 환자동선과 일반인 또는 의사의 동선의 구분되 어 별도의 출입이 이루어지지만 3CO8에서는 환자와 방문객 또는 의사의 동선의 혼합되는 것을 알 수 있다.

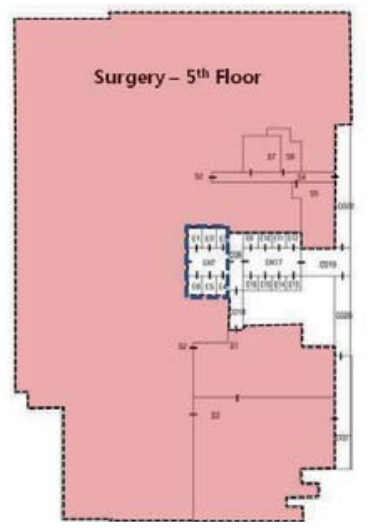

[Figure 25] Convex map of <Cmc-s>Hospital (Surgery) 


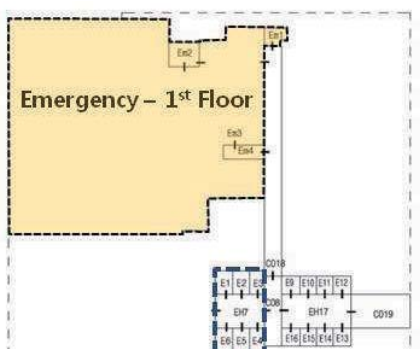

[Figure 26] Convex map of $<$ Cmc-s $>$ Hospital (Emergency)

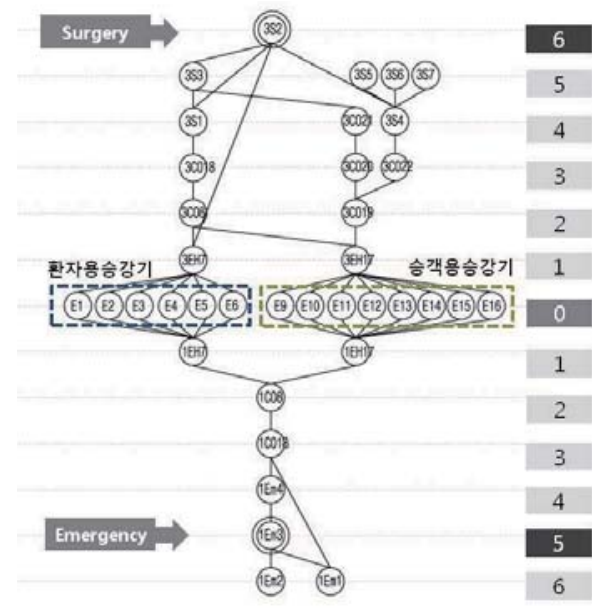

[Figure 27] Justified graph of $<\mathrm{Cmc}-\mathrm{s}>$ Hospital (Surgery Emergency)

\subsection{Depth of Meal Service Part - Wards Part}

조사병원의 급식부와 병동부의 공간구조를 분석하기 위 해 아래 그림과 같이 병동부의 평면을 볼록 공간도(Convex map)로 전환하여 나타냈다. 또한 공간의 연결 관계를 쉽게 볼 수 있게 공간위상도(J-graph)로 나타냈다. 사례병원의 급 식부는 별도의 배선용승강기가 모두 배치되어 있으며, 지하 급식부에서 따로 연결 가능하도록 설계되어 있어 병동부의 공간구조를 살펴보았다. 공간번호에 있어서는 각 공간의 특 성을 한눈에 파악하기 위해 병실을 포함한 환자공간과 간호 공간은 일련번호를 사용하여 표기하였으며, 공용공간인 승강 기는 $\mathrm{E}$, 승강기 홀은 $\mathrm{EH}$, 복도는 $\mathrm{CO}$, 계단은 $\mathrm{ST}$, 공용화장실은 $\mathrm{T}$ 의 약자를 실 번호 앞에 표기하였다.

[Table 3] Relations in the Movements between Meal Service part-Patient Wards part ${ }^{6)}$

\begin{tabular}{|c|c|c|c|c|c|c|c|c|c|c|}
\hline $\begin{array}{l}\text { 배 } \\
\text { 점 }\end{array}$ & $\begin{array}{l}\text { 급식부- } \\
\text { 병동부 }\end{array}$ & $\begin{array}{l}\text { D. } \\
\text { ․ } \\
\vdots 3\end{array}$ & 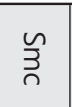 & 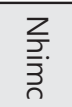 & $\begin{array}{l}\stackrel{n}{D} \\
\frac{\tilde{\sigma}}{\sigma}\end{array}$ & $\frac{\pi}{\hat{\jmath}}$ & ญ & $\begin{array}{l}\text { W } \\
3\end{array}$ & 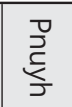 & $\begin{array}{l}\hat{n} \\
\hat{n} \\
\hat{n}\end{array}$ \\
\hline \multirow{4}{*}{2} & & V & V & V & V & V & V & V & V & V \\
\hline & 급식부 & 지하 & 지하 & 지하 & 지하 & 지하 & 지상 & 지하 & 지하 & 지하 \\
\hline & 층수 & 1 & 1 & 1 & 1 & 2 & 2 & 1 & 1 & 1 \\
\hline & $\begin{array}{c}\text { 병동부 } \\
\text { 층수 }\end{array}$ & $4 \sim 13$ & $6 \sim 20$ & $4 \sim 13$ & $4 \sim 13$ & $4 \sim 12$ & $\begin{array}{c}10 \\
\sim 20\end{array}$ & $5 \sim 11$ & $4 \sim 11$ & 9 21 \\
\hline
\end{tabular}

\section{1) Depth of $<$ Ajoumc $>$ Hospital}

<Ajoumc>병원은 이중복도에 사각형의 기본 형태를 가진 병동이다. 급식부에서 연결된 배선용 승강기 $(X)$ 는 중심 외주 부면에 면해 있어 비대칭 코어를 형성한다. 비상용승강기와 특별피난계단 2곳은 이중복도 양측 면에 대칭으로 배치되어 있는 복합코어이다. 대칭형평면에 대칭형코어인 <Ajoumc> 병원은 배선용승강기에 의해 비대칭코어의 형태를 가진다.

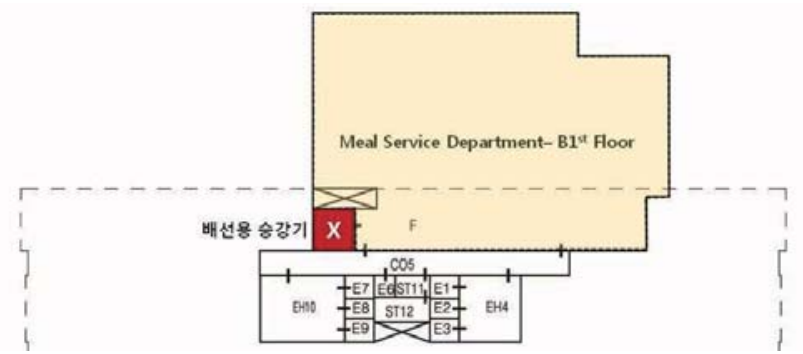

[Figure 28] Convex map of <Ajoumc $>$ Hospital (Meal Service)

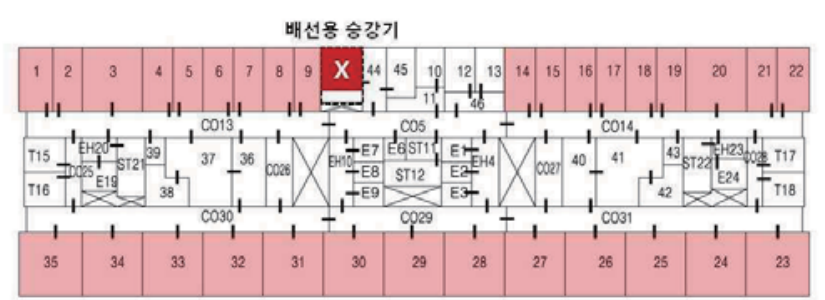

[Figure 29] Convex map of <Ajoumc $>$ Hospital (Wards)

지하의 급식부에서 올라온 배선용승강기를 통해 각 병실까 지 이동되는 공간의 깊이를 살펴보면 공간위상도에서 보이 듯 1 22번까지의 병실은 깊이 값 4를 나타내며, 28 30병실 은 깊이 값 $5,23 \sim 27$ 병실, 31 35병실은 깊이 값 6을 나타낸 다.

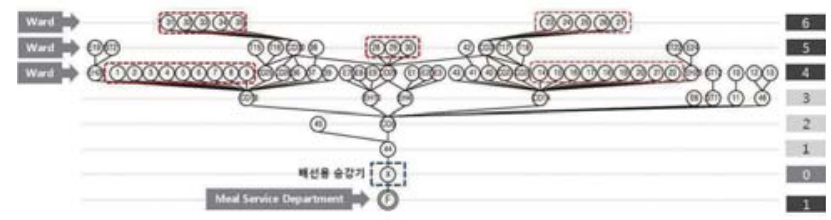

[Figure 30] Justified graph of <Ajoumc $>$ Hospital (Meal Service - Wards)

2) Depth of <Smc> Hospital

<Smc>병원은 편복도의 삼각형형태를 가진 병동이다. 급 식부에서 연결된 배선용 승강기 $(X)$ 는 메인코어와 면해 중앙

6) 이현진, 박재승, 환자중심의 수직코어 계획을 위한 종합병원 부 문간 상관배치에 관한 연구, 한국의료복지시설학회, 19권2호, 2013, pp37 
부분에 집중 배치되어 있어 별도의 연결 복도(CO18)에 의해 양측에 병실로 이동이 가능한 위치에 있다.

지하 1 층의 급식부에서 올라온 배선용승강기를 통해 각 병 실까지 이동되는 공간의 깊이를 살펴보면 아래의 공간위상 도에서 보이듯이 2 4, 11 13번 병실을 제외하고는 같은 공 간깊이를 보인다. 5 10번 병실, 15 22번, 24 31번 병실은 깊이 값 6 을 2 4번, 11 13번 병실은 깊이 값 7을 나타내어 사례병원 중 가장 깊은 깊이 값을 나타낸다.

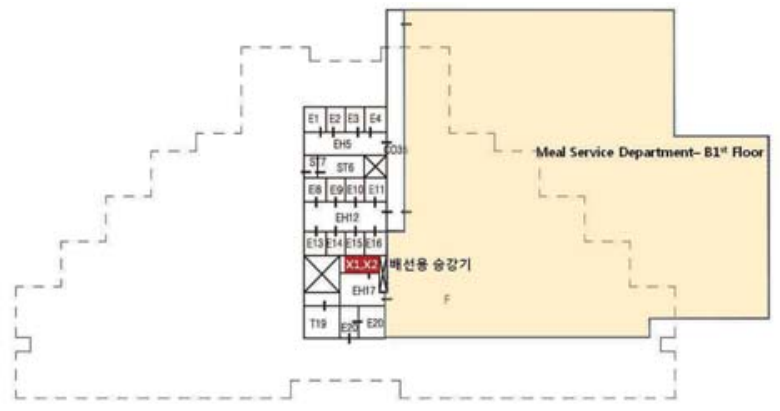

[Figure 31] Convex map of $<$ Smc $>$ Hospital (Meal Service)

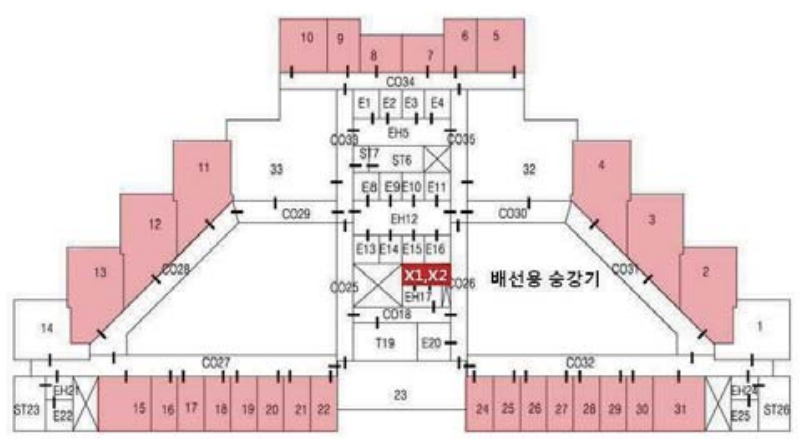

[Figure 32] Convex map of <Smc $>$ Hospital (Wards)

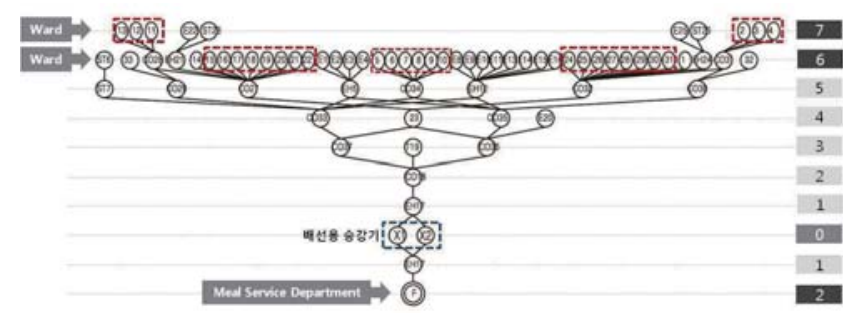

[Figure 33] Justified graph of <Ajoumc> Hospital (Meal Service - Wards)

삼각형 형태의 2 개가 결합한 병동에 변과 변이 만나는 곳 에 메인코어(환자용승강기, 승객용승강기, 배선용승강기, 피 난계단 등)가 배치되어 있으며, 사각형 양측 꼭짓점 부분에 비상용승강기와 피난계단이 배치되어 있는 형태이다. 복도는 2 개의 삼각형의 편복도가 중정을 중심으로 순환되는 형태를 가진 것이 특징이다.

\section{3) Depth of <Nhimc> Hospital}

<Nhimc>병원은 삼각형형태의 비대칭코어를 가진 병동이 다. 급식부에서 연결된 배선용 승강기는 메인코어와 별도로 반대편에 위치하며 삼각형의 각 변에 병실이 배치되며 중앙 중정을 중심으로 1 방향 순환하는 동선의 복도를 가진 병동이 다.

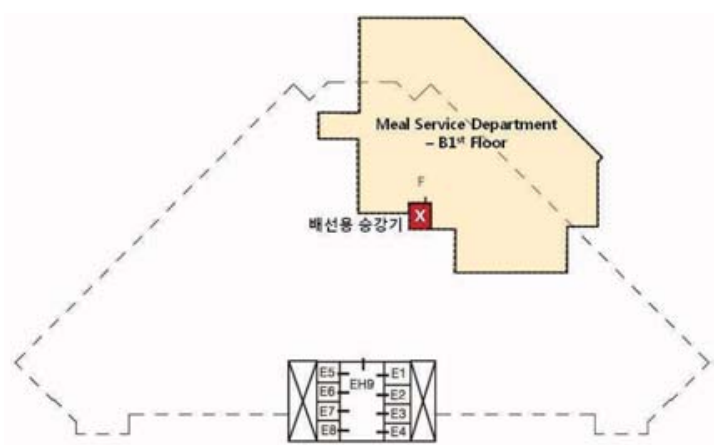

[Figure 34] Convex map of < Nhimc $>$ Hospital (Meal Service)

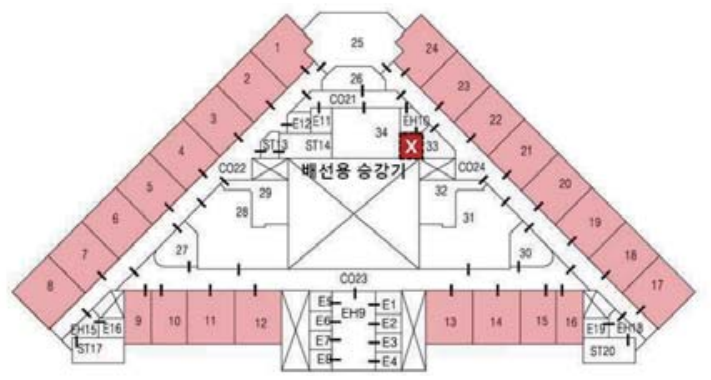

[Figure 35] Convex map of $<$ Nhimc $>$ Hospital (Wards)

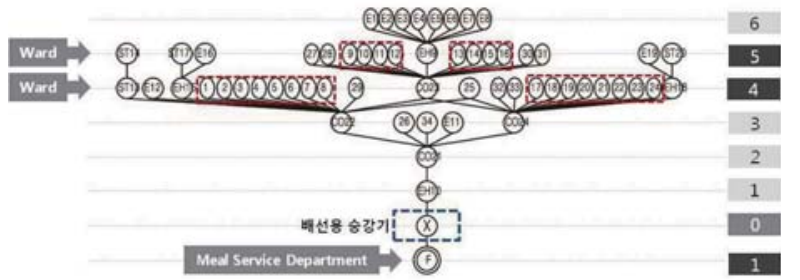

[Figure 36] Justified graph of $<$ Nhimc $>$ Hospital (Meal Service - Wards)

지하1층의 급식부에서 올라온 배선용승강기를 통해 각 병 실까지 이동되는 공간의 깊이를 살펴보면 아래의 공간위상 도에서 보이듯이 1 8번병실과 17 24번 병실은 깊이 값4를 나타내고, 메인코어와 면해 있는 9 16번 병실은 깊이 값 5 를 나타낸다.

4) Depth of <Snubh> Hospital

<Snubh>병원은 중복도의 $Y$ 의 비대칭코어를 가진 병동이 다. 그 중심에 메인코어가 환자용과 일반인용으로 분리되어 일 방향으로 열려있는 유형을 가진다. 급식부는 비대칭으로 
중앙에서 좌측으로 치우쳐 배치되며 교육연구시설이 Y형 병 동의 한쪽 변에 위치한다. 중복도에 면해 병실은 깊이 값 3 과 5 의 병실 깊이를 나타내는데, 이는 배선용 승강기가 비대 칭으로 배치되었기 때문이다. 중복도의 순환하지 않은 병동 기준층의 수평복도 동선은 공간위상도상에 비대칭의 형태를 나타내며, 지하 1 층의 급식부에서 올라온 배선용승강기를 통 해 각 병실까지 이동되는 공간의 깊이를 살펴보면 1 10번병 실과 38 42병실은 4의 깊이 값을 나타내며 14 28번 병실은 깊이 값 5 를 나타내는 비대칭의 형상이며 ST33은 10 단계의 가장 깊은 위치에 배치되어 있는데 이는 피난용 계단이다.

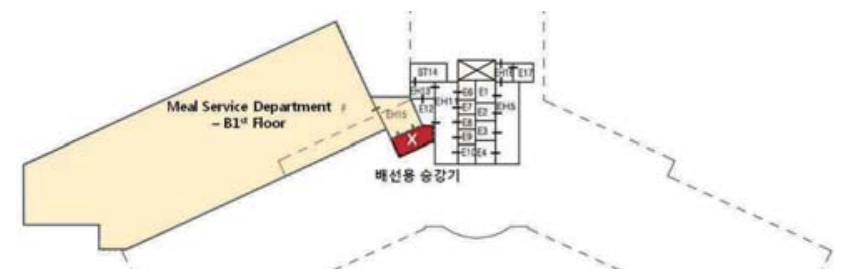

[Figure 37] Convex map of $<$ Snubh $>$ Hospital(Meal Service)

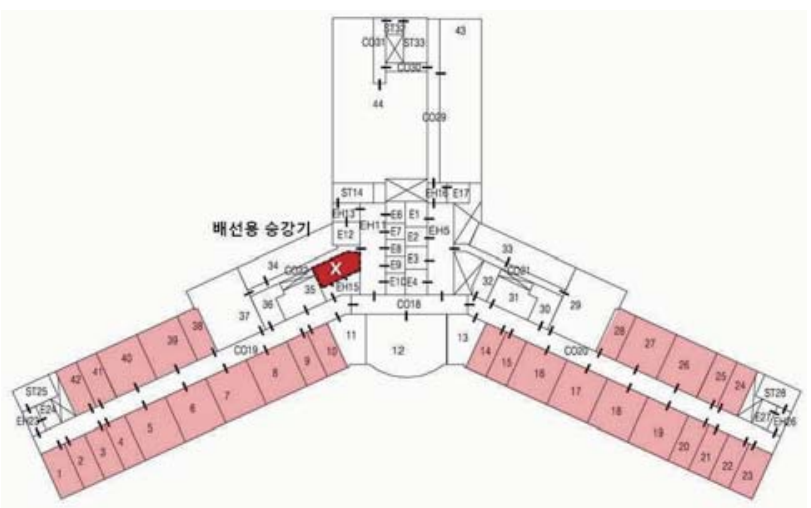

[Figure 38] Convex map of $<$ Snubh $>$ Hospital (Wards)

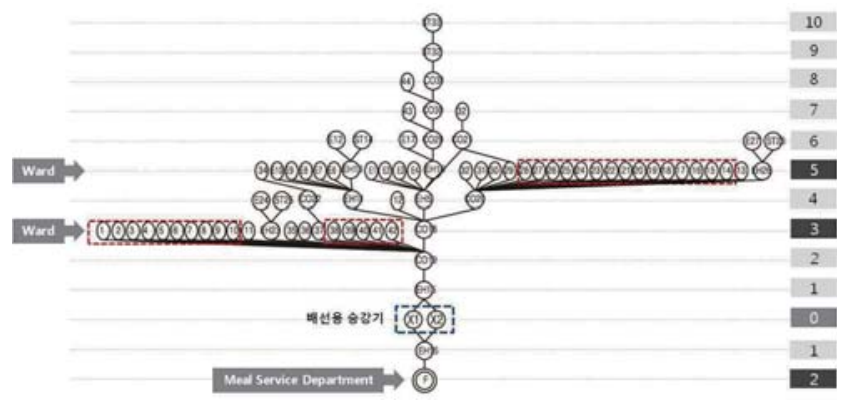

[Figure 39] Justified graph of $<$ Snubh $>$ Hospital (Meal Service - Wards)

5) Depth of <Kuh> Hospital

<Kuh>병원은 이중복도의 센터코어를 가진 가장 콤팩트한 평면을 가진 병원이다. 그 중심에 메인코어는 환자용승강기 와 승객용승강기가 혼합된 공용의 홀을 가지며 배선용승강 기는 중심의 메인코어와 인접해 배치되어 있다.

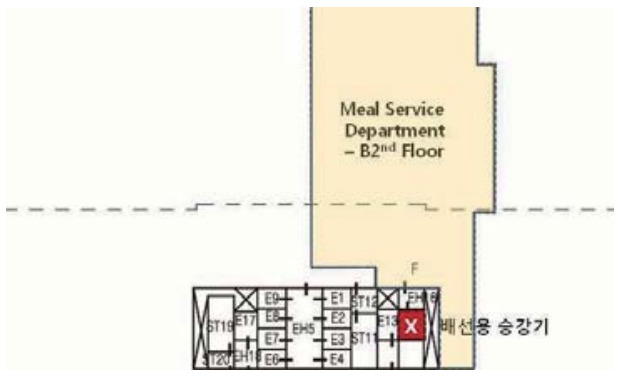

[Figure 40] Convex map of < Kuh $>$ Hospital (Meal Service)

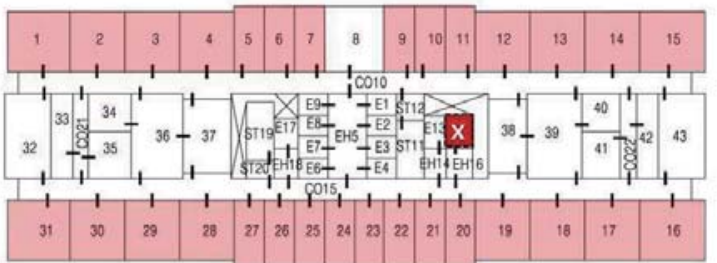

[Figure 41] Convex map of < Kuh $>$ Hospital (Wards)

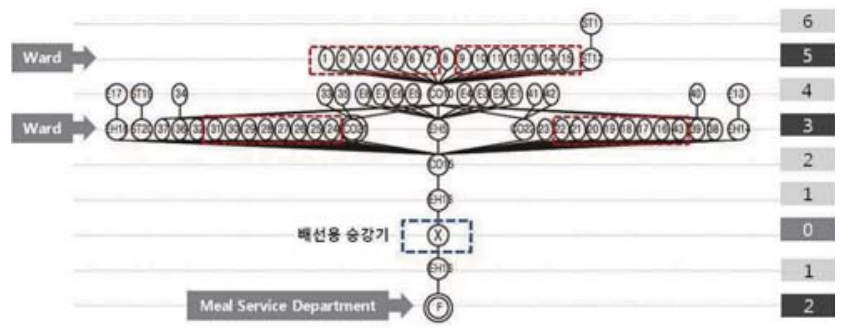

[Figure 42] Justified graph of $<$ Kuh $>$ Hospital (Meal Service - Wards)

지하1층의 급식부에서 올라온 배선용승강기를 통해 각 병 실까지 이동되는 공간의 깊이를 살펴보면 16 31번 병실은 3 의 깊이 값을 나타내며, 1 7, 9 15번 병실은 깊이 값 6을 나 타내는 대칭의 형태를 나타낸다.

6) Depth of <Sev> Hospital

<Sev> 병원은 2 개의 삼각형이 결합된 마름모꼴의 병상형 태를 가진다. 중앙에 메인코어가 환자용 승강기 홀과 일반인 용 승강기 홀이 공간적으로 분리되어 이격 배치되어 있다.

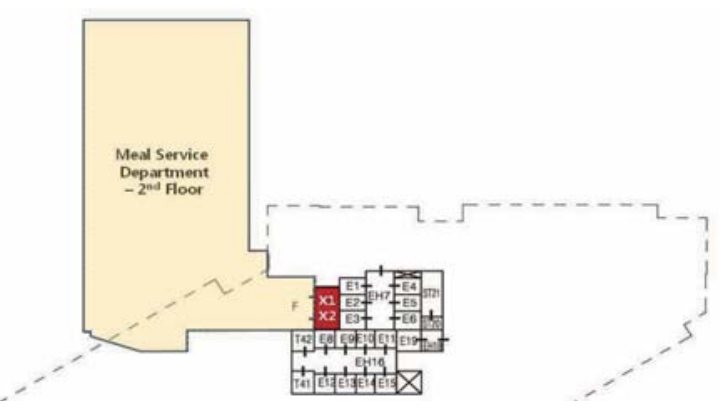

[Figure 43] Convex map of $<$ Sev $>$ Hospital (Meal Service) 


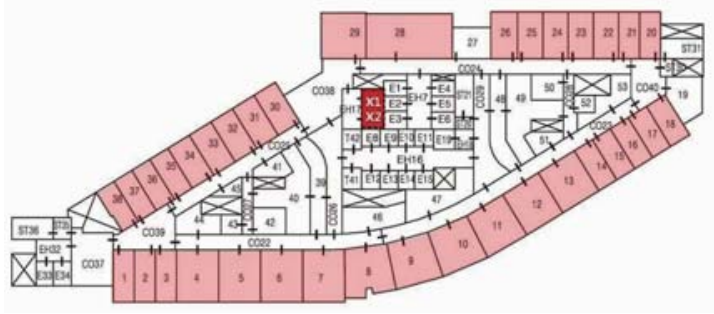

[Figure 44] Convex map of <Sev> Hospital (Wards)

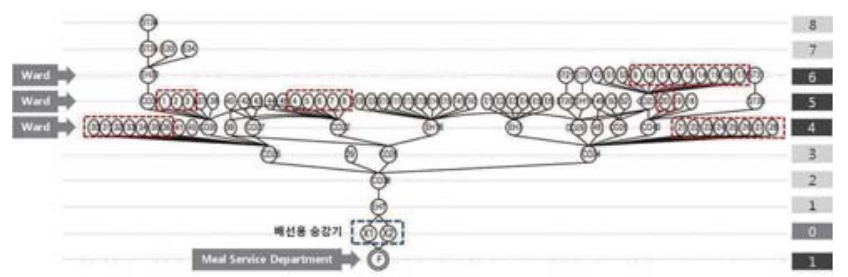

[Figure 45] Justified graph of $<$ Sev $>$ Hospital (Meal Service - Wards)

하지만 코어 뿐만아니라 병실의 배치 또한 비대칭으로 변 형된 형태로 삼각형의 꼭짓점마다 공용의 공간이 계획되어 깊이 감을 더해주며, 병실은 $4,5,6$ 의 3 단계의 깊이 값을 나타 났다.

7) Depth of <Bsm> Hospital

$<\mathrm{Bsm}>$ 병원은 삼각형의 중심에 환자용승강기, 승객용승강 기의 메인코어가 콤팩트하게 배치되어 있는 형태로 배선용 승강기 또한 중심코어에 배치되어 있는 중심성이 강한 코어 의 형태를 가진다. 승강기홀(EH8)은 중심을 관통하는 동선으 로 병동부 순환복도의 메인복도 역할을 한다. 꼭짓점 2곳에 비상용승강기와 피난계단에 배치되어 있는 순환형 복도를 가진다. 병실은 3 4 6의 3단계의 깊이 값을 가지는 구성형 태로 전체 7단계의 깊이를 구성한다.

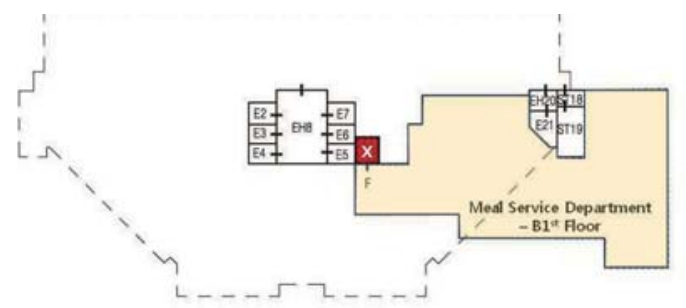

[Figure 46] Convex map of <Bsm>Hospital (Meal Service)

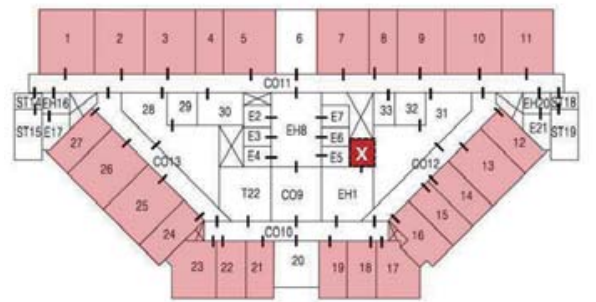

[Figure 47] Convex map of <Bsm>Hospital (Wards)

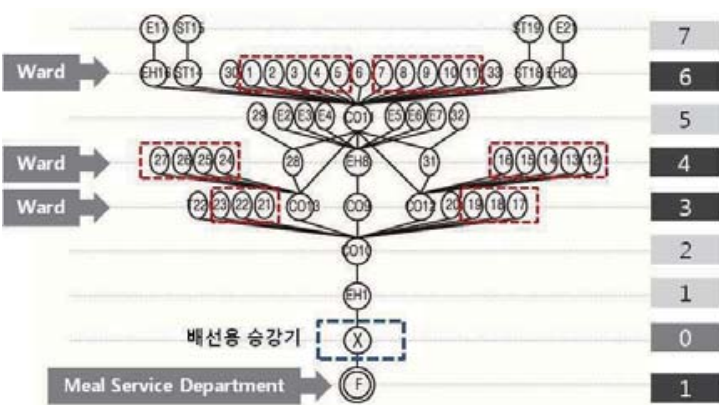

[Figure 48] Justified graph of <Bsm > Hospital (Meal Service - Wards)

\section{8) Depth of <Pnuyh> Hospital}

이중복도의 사각형 기본 형태를 가진 <Pnuyh>병원은 중 심에 메인코어가 배치되고, 배선용승강기는 중심의 메인코어 에 인접해 배치되어 있으며, 복도 양측면 끝에 서브코어가 배 치되어 있어있다. 병실은 깊이3과 5의 사례병원 중 가장 적 은 깊이 값을 가진다. 급식부는 다른 사례병원과 마찬가지로 2 의 깊이 값으로 배선용승강기에서 바로 급식부 주방이 배치 됨을 알 수 있다. 수평형 병원의 대표사례인 <Pnuyh>병원은 다른 수직형 병원과 병동코어의 형태에 있어 특이할만한 차 이점을 가지지 않은 것이 특징이다.

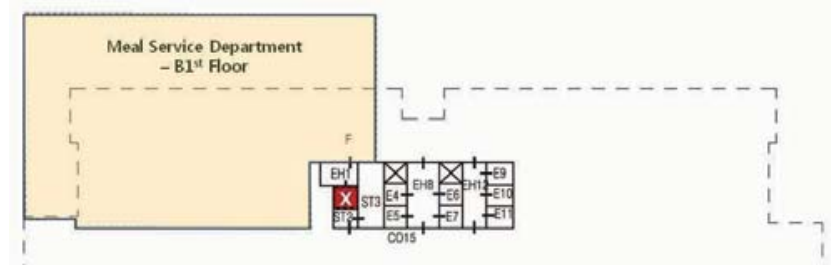

[Figure 49] Convex map of <Pnuyh $>$ Hospital (Meal Service)

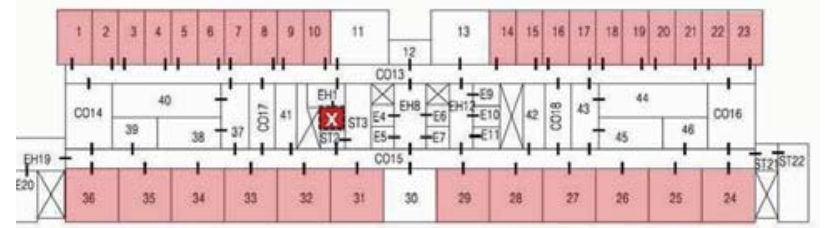

[Figure 50] Convex map of < Pnuyh $>$ Hospital (Wards)

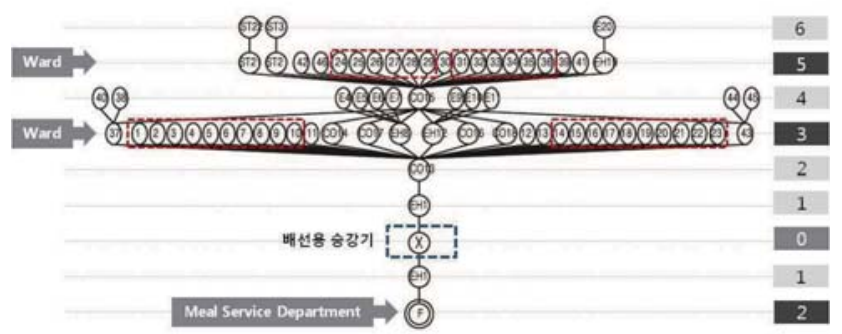

[Figure 51] Justified graph of <Pnuyh $>$ Hospital (Meal Service - Wards) 
9) Depth of <Cmc-s> Hospital

$<\mathrm{Cmc}-\mathrm{s}>$ 병원은 이중복도의 대칭평면을 가진 사각형 병원 으로 그 중심에 메인코어가 있으며 배선용승강기는 메인코 어에 인접하지만 외주부에 치우친 복도에 면해있어서 공간 위상도가 비대칭으로 형성됨을 알 수 있다.

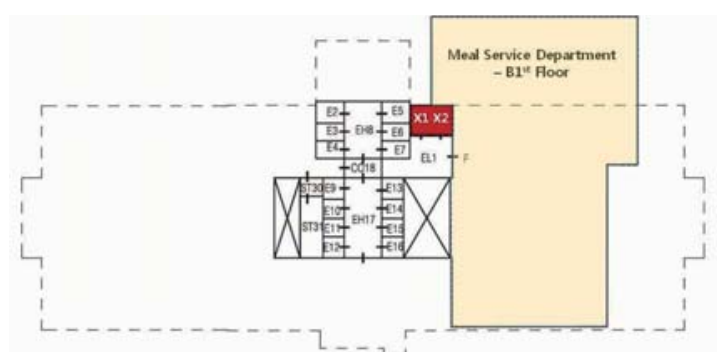

[Figure 52] Convex map of <Cmc-s $>$ Hospital (Meal Service)

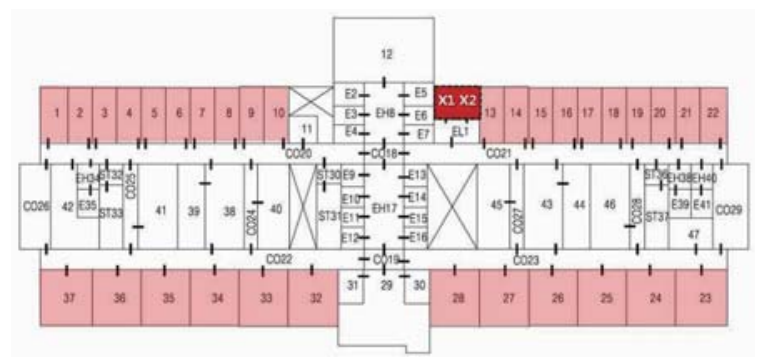

[Figure 53] Convex map of $<$ Cmc-s $>$ Hospital (Wards)

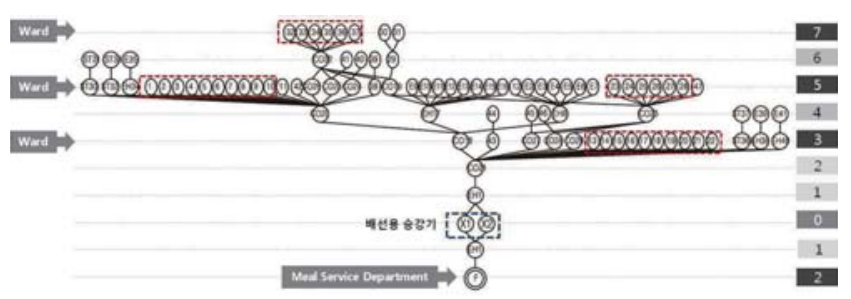

[Figure 54] Justified graph of $<$ Cmc-s $>$ Hospital (Meal Service - Wards)

다른 이중복도형의 병동평면이 대칭의 공간위상도를 보 이는데 반해 <Cmc-s>병원은 확연하게 비대칭의 공간관계 가 보임을 알 수 있다. 13 22번 병실은 깊이 값 3, 1 10번, 23 28번 병실은 깊이 값 5, 32 37번 병실은 깊이 값 7로 다 양하게 나타나는 것을 알 수 있다.

\section{Conclusion}

본 연구는 종합병원 이용 시 환자의 부문 간 이동에 중추 적 기능을 하며, 병원형태결정에 중요한 역할을 하는 수직코 어의 배치 계획의 가이드라인을 제공하기 위해 시도되었다.

응급을 필요로 하고 이동빈도가 높은 환자의 부문 간의 연결은 수평적 배치의 비중이 높은데 반해, 이동 빈도가 낮으
며 응급의 정도가 낮은 부문 간 연결은 수직적 배치가 이루 어지고 있다. 하지만, 연결의 중요도가 높은 부문 중에 수직 배치되어진 수술부와 응급부, 급식부와 병동의 경우 메인코 어로 이동 되어야 하므로, 감염과 신속성이 고려된 수직동선 의 배치계획이 필요하다. 부문 간 수직배치 되어 있는 경우에 는 코어와의 배치, 환자용승강기홀의 공유 유무, 환자용승강 기 인접복도 방향에 영향을 주고 있는 것이 보여진다.

1) 수술부와 응급부의 공간 깊이로 본 기능연계성

사례병원의 수술부와 응급부는 모두 수직 배치된 경우로 응급환자의 스트레쳐에 의한 신속하고 독립된 동선이 요구 되는 기능실 간의 관계이다.

[Table 4] Character of Operation part - Emergency part

\begin{tabular}{|c|c|c|c|c|c|c|c|c|c|c|c|c|}
\hline \multirow{2}{*}{$\begin{array}{l}\text { 병원 } \\
\text { 병원 }\end{array}$} & \multicolumn{2}{|c|}{ 공간깊이 } & \multicolumn{2}{|c|}{ 단면조닝 } & \multicolumn{2}{|c|}{$\begin{array}{l}\text { 수술부- } \\
\text { 코어관계 }\end{array}$} & \multicolumn{2}{|c|}{$\begin{array}{l}\text { 응급부- } \\
\text { 코어배치 }\end{array}$} & \multicolumn{2}{|c|}{$\begin{array}{c}\text { 환자용 } \\
\text { 승강기홀 }\end{array}$} & \multicolumn{2}{|c|}{$\begin{array}{c}\text { 환자 } \\
\text { 승강기 } \\
\text { 복도 }\end{array}$} \\
\hline & $\begin{array}{l}\text { 수술부 } \\
\text {-코어 }\end{array}$ & $\begin{array}{l}\text { 응급븝 } \\
\text {-코어 }\end{array}$ & $\begin{array}{l}\text { 상하 } \\
\text { 집중 }\end{array}$ & $\begin{array}{l}\text { 상하 } \\
\text { 독립 }\end{array}$ & \begin{tabular}{|l} 
인접 \\
배치
\end{tabular} & $\begin{array}{l}\text { 이격 } \\
\text { 배치 }\end{array}$ & $\begin{array}{l}\text { 인접 } \\
\text { 배치 }\end{array}$ & $\begin{array}{l}\text { 이격 } \\
\text { 배치 }\end{array}$ & 별도 & 공유 & $\begin{array}{c}1 \\
\text { 방향 }\end{array}$ & 2 \\
\hline Smc & 7 & 5 & & 0 & & 0 & 0 & & 0 & & & 0 \\
\hline Cmc-s & 6 & 5 & 0 & & 0 & & & 0 & 0 & & 0 & \\
\hline Sev & 4 & 4 & 0 & & 0 & & 0 & & 0 & & 0 & \\
\hline Ajoumc & 3 & 4 & 0 & & 0 & & 0 & & 0 & & 0 & \\
\hline Snubh & 7 & 5 & 0 & & 0 & & & 0 & 0 & & 0 & \\
\hline Kuh & 5 & 4 & & 0 & 0 & & 0 & & & 0 & & 0 \\
\hline Pnuyh & 6 & 5 & & 0 & 0 & & & 0 & 0 & & & 0 \\
\hline Nhimc & 7 & 5 & 0 & & 0 & & & 0 & & 0 & 0 & \\
\hline Bsm & 4 & 5 & 0 & & 0 & & & 0 & & 0 & & 0 \\
\hline
\end{tabular}

수술부와 코어의 깊이가 가장 낮은 $\langle\mathrm{Sev}$ 병원과 <Ajoumc>병원의 특징을 살펴본 결과 단면상 부서의 위치가 환자용승강기를 중심으로 상하 집중배치 되어있으며 환자용 승강기는 승객용승강기와 완전 분리되어 환자의 독립된 출 입이 가능하며, 수술부, 응급부의 진입구와 단독의 출입이 가 능하도록 계획되어 있다. 또한 승강기 홀은 보호자나 방문객 과의 동선 혼란을 피하기 위해 1 방향 복도에 면하도록 승강 기 홀이 계획되었음을 알 수 있었다.

수평형병원인 <Smc>병원은 병동의 메인코어를 사용하지 만 수술부와 연결브리지로 연결되어 있어 깊이값이 높게 나 타났으며, <Pnuyh>병원은 별도의 환자용 승강기가 수술부 에 인접하여 배치되었지만 출입구의 위치가 너무 이격되어 배치되었다.

2) 급식부와 병동부의 공간 깊이로 본 기능연계성

사례병원의 공간깊이를 살펴본 결과 병동부의 배선용승 강기에서 각 병실까지의 깊이 값은 낮게는 3 에서 높게는 7 까지 나타났다. 병동부에서 가장 낮은 깊이 값을 나타내는 <Snubh>병원과 <Kuh>병원, <Pnuyh>병원의 배선용승강기 는 병동의 중심부에 배치되어 있는 특징을 가진다. 중복도의 
형태로 순환하지 않는 복도를 가진 <Snubh>병원만 공간위 상도상 병실이 비대칭 되며 <Kuh>병원은 대칭의 평면과 대 칭의 코어로 가장 낮은 깊이 값을 가진다.

[Table 5] Character of Meal Service Part - Wards Part

\begin{tabular}{|c|c|c|c|c|c|c|c|c|c|c|c|}
\hline \multirow{2}{*}{ 병원 } & \multicolumn{2}{|c|}{ 공간깊이 } & \multicolumn{2}{|c|}{$\begin{array}{c}\text { 병동부- } \\
\text { 코어관계 }\end{array}$} & \multicolumn{2}{|c|}{$\begin{array}{l}\text { 급식부- } \\
\text { 코어배치 }\end{array}$} & \multicolumn{2}{|c|}{$\begin{array}{l}\text { 배선용 } \\
\text { 승강기 }\end{array}$} & \multicolumn{2}{|c|}{$\begin{array}{l}\text { 공간위상 } \\
\text { 병실배치 }\end{array}$} & \multirow{2}{*}{$\begin{array}{l}\text { 병동 } \\
\text { 복도 }\end{array}$} \\
\hline & $\begin{array}{c}\text { 병실 } \\
\text {-코어 }\end{array}$ & $\begin{array}{l}\text { 급식부 } \\
\text {-코어 }\end{array}$ & $\begin{array}{l}\text { 인접 } \\
\text { 배치 }\end{array}$ & $\begin{array}{l}\text { 이격 } \\
\text { 배치 }\end{array}$ & $\begin{array}{l}\text { 인접 } \\
\text { 배치 }\end{array}$ & $\begin{array}{l}\text { 이격 } \\
\text { 배치 }\end{array}$ & $\begin{array}{l}\text { 외주 } \\
\text { 부 }\end{array}$ & $\begin{array}{l}\text { 중심 } \\
\text { 부 }\end{array}$ & 대칭 & \begin{tabular}{|c|} 
비 \\
대칭
\end{tabular} & \\
\hline Smc & $6 / 7$ & 2 & 0 & & 0 & & & 0 & 0 & & $\begin{array}{l}\text { 순환형 } \\
\text { 편복도 }\end{array}$ \\
\hline Cmc-s & $3 / 5 / 7$ & 2 & 0 & & 0 & & 0 & & & 0 & $\begin{array}{l}\text { 이중 } \\
\text { 복도 }\end{array}$ \\
\hline Sev & $4 / 5 / 6$ & 1 & 0 & & 0 & & & 0 & & 0 & 순환형 \\
\hline Ajoumc & $4 / 5 / 6$ & 1 & 0 & & 0 & & 0 & & 0 & & $\begin{array}{l}\text { 이중 } \\
\text { 복도 }\end{array}$ \\
\hline Snubh & $3 / 5$ & 2 & 0 & & 0 & & & 0 & & 0 & 중복도 \\
\hline Kuh & $3 / 5$ & 2 & 0 & & 0 & & & 0 & 0 & & $\begin{array}{l}\text { 이중 } \\
\text { 복도 }\end{array}$ \\
\hline Pnuyh & $3 / 5$ & 2 & 0 & & 0 & & & 0 & 0 & & $\begin{array}{l}\text { 이중 } \\
\text { 복도 }\end{array}$ \\
\hline Nhimc & $4 / 5$ & 1 & 0 & & 0 & & & 0 & 0 & & 순환형 \\
\hline Bsm & $3 / 4 / 6$ & 1 & 0 & & 0 & & & 0 & 0 & & 순환형 \\
\hline
\end{tabular}

<Smc>병원은 병실의 깊이가 상대적으로 다른 병원보다 깊은 것을 알 수 있는데, 이는 순환형 편복도의 삼각형 병동 에서 오는 동선에 의한 것이라 판단한다.

비대칭형의 병동 형태를 가진 <Sev> 병원과 <Cmc-s> 병 원의 경우 확연하게 비대칭의 공간위상도의 형태를 보여주 고 있다. 배선용 승강기는 대부분 한쪽측면에 비대칭으로 배 치되는 사례가 많지만, 하루에 3회의 배식을 위한 동선임을 고려할 때 각 병실에서 동일한 깊이로 배치 될 수 있는 위치 에 배치하는 것이 바람직하다.

\section{References}

1. Cho, Young-Hang, 2010.7, "The Space Characteristics of Dementia Units by Using Space Syntax Theory", Journal of Architectural Institute of Korea Vol.29 No.4, pp. 27-34

2. Kim, Young-Ook, 2001.6, "Application of Space Syntax in Hospital Planning and Design", Journal of Korea Institute of Healthcare Architecture, Vol.7, No.2, pp. 97-102

3. Lee Hyun-Jin, Park Jae-Seung, 2013.5, "A Study on Correlation between Departments Layout of General Hospitals for Patientcentered Vertical Core Plan", Journal of Korea Institute of Healthcare Architecture, Vol.19, No.2, pp. 31-40

4. Lee, Soo-Kyung, 2009.8, A Study on the Spatial Configuration and Typological Characteristics of Public Libraries in Korea Focused on depth and browsing circuit of space syntax, Ph.D Dissertation, Department of Architecture Graduate School
Hanyang University

5. Yang, Nae-Won, Kim Young-Seung, 1997.12, A Study on the Evaluation of the Spatial Configuration in General Hospitals By Space Syntax, Journal of Korea Institute of Healthcare Architecture, Vol.3, No.5, pp. 79-85

$$
\text { 접수 : 2013년 09월 26일 }
$$
1차 심사 완료 : 2013년 10월 19일 게재확정일자 : 2013년 10월 19일 3인 익명 심사 필 